\title{
HIV-Associated Multinucleated Giant Cells in Lymphoid Tissue of the Waldeyer's Ring: A Detailed Study
}

\author{
Jean-Louis Dargent, M.D., Laurence Lespagnard, Ph.D., Anne Kornreich, M.D., \\ Philippe Hermans, M.D., Ph.D., Nathan Clumeck, M.D., Ph.D., Alain Verhest, M.D., Ph.D. \\ Department of Pathology (JLD, LL, AV), CHU Saint-Pierre/ULB-Institut Jules Bordet; Department of \\ Immunology and Haematology (AK), ULB-Hôpital Erasme; and Department of Infectious Diseases (PH, \\ NC), CHU Saint-Pierre, Brussels, Belgium.
}

Hyperplastic lymphoid tissues of the Waldeyer's ring in human immunodeficiency virus (HIV)-infected patients may occasionally contain multinucleated giant cells (MGCs). These cells, which are unrelated to any opportunistic infection, previously have been demonstrated to harbor significant amounts of HIV. Studies undertaken to characterize these MGCs have generated conflicting results: some reports suggested a macrophage origin, whereas others supported a dendritic cell lineage. This study was performed to determine the occurrence of MGCs in a series of adenoid/tonsil specimens from HIV-seropositive patients showing no histological evidence of opportunistic infection in order to further characterize the phenotype of these cells and to investigate the role of a viral infection in their pathogenesis. Adenoid/tonsil tissue specimens from $21 \mathrm{HIV}$-seropositive patients with no documented opportunistic infection were scrutinized for the presence of MGCs and evaluated immunohistochemically on paraffin sections by antibodies directed against various macrophage and DC antigens. These antigens included CD68, the macrophage marker 3A5, major histocompatibility complex Class II, S-100 protein, CD1a, and CD83. Additional immunostainings directed at CD21 and CD35 as well as at the HIV-associated p24 antigen were also performed. Finally, the presence of Epstein-Barr virus and human herpesvirus 8 viral sequences was investigated by in situ hybridization and by polymerase chain reaction analysis, respectively. MGCs were found in 14 patients $(66.7 \%)$, regardless of gender, age, method of viral transmission, CD4 cell count, viral load, or ethnic group. These cells were mostly localized at the lymphoepi-

Copyright () 2000 by The United States and Canadian Academy of Pathology, Inc.

VOL. 13, NO. 12, P. 1293, 2000 Printed in the U.S.A.

Date of acceptance:

Address reprint requests to: Jean-Louis Dargent, M.D., Department of Pathology, Institut Jules Bordet, 1 rue Héger-Bordet, 1000 Brussels, Belgium; e-mail: jldargent@hotmail.com; fax: 3225347910. thelium layer of the tonsillar crypts and, to a lesser extent, in the interfollicular areas of the underlying lymphoid tissue, which consistently exhibited features of follicular hyperplasia. Phenotypically, MGCs were found to be $\mathrm{CD}^{+} 8^{+}, 3 \mathrm{A5}^{+}$, major histocompatibility complex Class $\mathrm{II}^{+}, \mathrm{S}-100$ protein $^{+/-}$, $\mathrm{CD}^{-}, \mathrm{CD}^{-}{ }^{-}, \mathrm{CD}^{-}$, and $\mathrm{CD}^{-}{ }^{-}$. Although the HIV-associated p24 protein was consistently present in the cytoplasm of these cells, no sign of Epstein-Barr virus or human herpesvirus 8 infection could be demonstrated. Consequently, our study didn't show any conclusive evidence to support that MGCs in hyperplastic lymphoid tissues of the Waldeyer's ring from HIV-seropositive patients originated from dendritic cells. The definite nature of these cells has yet to be elucidated, but it is plausible that they simply represent activated macrophages that are infected with HIV present in the oropharyngeal secretions during the circulation of their precursor through the lymphoepithelium area of adenoids and tonsils.

KEY WORDS: Adenoid, EBV, HHV-8, HIV infection, Multinucleated giant cell, Tonsil.

Mod Pathol 2000;13(12):1293-1299

As in the lymph nodes, the lymphoid tissue of the Waldeyer's ring (WR) may be infected by the human immunodeficiency virus (HIV; 1,2 ). In this setting, miscellaneous pathological changes that are closely related to this retroviral infection or to its various complications have been reported $(1,2)$. Among these, a somewhat underrecognized and intriguing feature is the occasional presence of multinucleated giant cells (MGCs) in hyperplastic lymphoid tissue of the WR (2-10). These cells mostly occur isolatedly or in small clusters at the lymphoepithelium layer of the tonsillar crypts and strikingly resemble those previously described in brain and spinal cord tissues of patients with acquired immune deficiency syndrome (AIDS)-related encephalopathy and myelopathy, respectively 
(2-10). Similar cells were also documented in a case of nodal lymphoma associated with AIDS (11), in HIV-associated lymphoepithelial cysts of the parotid gland (12), and more recently, in the colonic mucosa of an HIV-seropositive man (13). These MGCs seem to be unrelated to any opportunistic agent, Epstein-Barr virus included, and they are known to harbor significant amounts of both HIV genomic sequences and viral products (3-13). These cells are morphologically distinct from Warthin-Finkeldey polykaryocytes and rather look more like Langhans'-type MGCs (9). Studies undertaken in order to assess their lineage have generated conflicting results: some reports advocated a macrophage origin $(8,10,13)$, whereas others claimed a dendritic cell (DC) lineage, not only because of their S-100 protein and p55 (fascin) expression but also because of their striking resemblance to the virus-producing DC-T cell syncytia that are observed in in vitro studies $(4-7,14,15)$. In an attempt to resolve the controversy surrounding the nature of these cells, we performed a phenotypic study using a panel of antibodies directed against various macrophage, follicular dendritic cell (FDC), and DC antigens. In addition, the issue of a viral infection in the pathogenesis of these MGCs was also addressed by searching for the presence of HIV, Epstein-Barr virus (EBV), and human herpesvirus 8 (HHV-8) viral products.

\section{MATERIALS AND METHODS}

Twenty-four adenoid/tonsil tissue samples from 21 patients known to be seropositive for HIV virus and showing no histological evidence of opportunistic infection were collected for this study. Tissue samples were obtained either from biopsies or from surgically resected specimens. All were fixed in formalin, conventionally processed, and embedded in paraffin wax. Histological sections were stained with hematoxylin and eosin. Each slide was carefully reviewed and scrutinized for the presence of MGCs. The main clinical data and the most relevant morphological features of the lymphoid tissue were recorded for each case (Tables 1 and 2).

\section{Immunohistochemistry}

Immunophenotypic studies were performed on paraffin sections using a Ventana Nexes Staining System (Ventana Medical Systems, Tucson, AZ). Antibodies directed against the following antigens were used: HIV-related p24 protein, CD21, CD35, S-100 protein, CD68 (PG-M1 clone; 16), major histocompatibility complex (MHC) Class II (DAKO A/S Glostrup, Glostrup, Denmark); CD1a (Immunotech SA, Marseille, France); and CD83 (Serotec, Oxford, UK). In addition, the monoclonal antibody 3A5
(Novocastra Laboratories Ltd, Newcastle-uponTyne, UK) that recognizes a formalin-resistant epitope present on macrophages and monocytes but virtually absent from DCs was also used for this study (17).

\section{Detection of EBV by In Situ Hybridization}

To investigate the possible role of EBV infection in the pathogenesis of MGCs, an in situ hybridization for EBV-encoded RNA transcripts was performed, using a supersensitive in situ hybridization detection system (BioGenex, San Ramon, CA).

\section{Detection of HHV-8 by Polymerase Chain \\ Reaction Analysis}

Paraffin-embedded tissues were cut into 5- $\mu \mathrm{m}$ thick sections. Three sections of each samples were put into an Eppendorf tube and deparaffinized twice by adding $1 \mathrm{~mL}$ of toluol, incubated for 5 minutes, and then centrifuged for 5 minutes at $13,000 \mathrm{rpm}$. Samples were then treated twice by adding $1 \mathrm{~mL}$ ethanol $100 \%$, incubated for $5 \mathrm{~min}$ utes, and centrifuged for 5 minutes at 13,000 rpm.

The pellet was then resuspended in TE buffer (20 mм Tris, 1 mм EDTA; pH 8.5) containing $200 \mu \mathrm{g} / \mathrm{mL}$ proteinase K (Roche Molecular Biochemicals, Brussels, Belgium) and incubated overnight at $55^{\circ} \mathrm{C}$. It was then heated at $95^{\circ} \mathrm{C}$ for 10 minutes to inhibit proteinase K. After a last centrifugation at 13,000 rpm for 5 minutes, $5 \mu \mathrm{L}$ of the supernatant was used for polymerase chain reaction (PCR) amplification.

As a control for gene amplification, the following $\mathrm{PCO} 3$ and $\mathrm{PCO} 4$ primers derived from the $\beta$-globin gene, giving an amplified fragment of 110 base pairs (bp), were used: PCO3: 5' -ACACAACTGTGTTCACTAGC-3' and PCO4: 5'-CAACTTCATCCACGTTCACC-3'.

The PCR mixture contained $10 \mathrm{~mm}$ Tris- $\mathrm{HCl}(\mathrm{pH}$ 9), $50 \mathrm{~mm} \mathrm{KCl,} 0.1 \%$ Triton $\mathrm{X}-100$, $2.5 \mathrm{~mm} \mathrm{MgCl}_{2}, 200$ $\mu \mathrm{M}$ dNTP, 10 picomoles of each primer, and $1 \mathrm{U}$ DNA Taq polymerase (Promega, A.J. Leiden, The Netherlands) in a final volume of $50 \mu \mathrm{L}$. Reactions were incubated in a Perkin-Elmer Thermocycler 2400 for 35 cycles (denaturation: $1 \mathrm{~min}$ at $94^{\circ} \mathrm{C}$, annealing: $1 \mathrm{~min}$ at $55^{\circ} \mathrm{C}$, elongation: $1 \mathrm{~min}$ at $72^{\circ}$ C). After amplification, $18 \mu \mathrm{L}$ of the PCR product was run on a $2 \%$ agarose gel stained with ethidium bromide.

Samples showing amplifiable DNA were then investigated for their putative HHV-8 content. Primers derived from the HHV-8 genome promoting the amplification of a 111-bp product from 987 to $1097 \mathrm{bp}$ of the published sequence (18) were used as follows: forward primer, 5' AGCCGAAAGGATTCCACCAT-3' and reverse primer, $5^{\prime}$-GTACACCAACAGCTGCTGCA- 
TABLE 1. Summary of Clinical Features

\begin{tabular}{|c|c|c|c|c|c|c|c|}
\hline $\begin{array}{l}\text { Case } \\
\text { Number }\end{array}$ & $\begin{array}{l}\text { Sex } \\
(\mathrm{M} / \mathrm{F})\end{array}$ & $\begin{array}{l}\text { Age } \\
\text { (Years) }\end{array}$ & $\begin{array}{l}\text { Anatomic } \\
\text { Location }\end{array}$ & Clinical Data & $\begin{array}{l}\text { Ethnic Group/Mode of } \\
\text { HIV Transmission }\end{array}$ & $\begin{array}{c}\text { CD4 Count } \\
(\mu \mathrm{l}) / \text { viral load } \\
\text { (copies/mL)* }\end{array}$ & $\begin{array}{l}\text { HIV Status at Time } \\
\text { of Biopsy**/ } \\
\text { Follow-Up }\end{array}$ \\
\hline 1 & M & 38 & Palatine tonsils & Enlargement & Caucasian/bisexual & $110 / \mathrm{NA}$ & $\begin{array}{l}\text { C/DOD within the } \\
\text { year }\end{array}$ \\
\hline 2 & M & 30 & Adenoids & $\begin{array}{l}\text { Mass, recurrent } \\
\text { otitis }\end{array}$ & Caucasian/bisexual & NA/NA & $\begin{array}{l}\text { NA/lost for follow- } \\
\text { up }\end{array}$ \\
\hline 3 & M & 36 & Palatine tonsils & Enlargement & Caucasian/NA & NA/NA & NA/NA \\
\hline 4 & M & 27 & Adenoids & Enlargement & Caucasian/homosexual & NA/NA & $\begin{array}{l}\text { A/AIDS } 8 \text { years } \\
\text { later }\end{array}$ \\
\hline 5 & M & 49 & Palatine tonsils & Enlargement & Caucasian/homosexual & 389/NA & $\mathrm{B} /$ alive \\
\hline 6 & $\mathrm{~F}$ & 48 & Adenoids & Enlargement & African/heterosexual & 226/NA & $\begin{array}{l}\text { B/alive } 2 \text { years } \\
\text { later, then lost } \\
\text { for follow-up }\end{array}$ \\
\hline 7 & $\mathrm{~F}$ & 21 & $\begin{array}{l}\text { Adenoids, } \\
\text { palatine } \\
\text { tonsils }\end{array}$ & NA & African/heterosexual & $<100 / \mathrm{NA}$ & $\mathrm{B} /$ alive \\
\hline 8 & M & 29 & Adenoids & Enlargement & Caucasian/homosexual & NA/NA & $\begin{array}{l}\text { A/DOD } 3 \text { years } \\
\text { later }\end{array}$ \\
\hline 9 & $\mathrm{~F}$ & 32 & Adenoids & $\begin{array}{l}\text { Enlargement, } \\
\text { postnasal } \\
\text { discharge }\end{array}$ & Caucasian/heterosexual & 945/NA & A/alive \\
\hline 10 & F & 38 & $\begin{array}{l}\text { Adenoids, } \\
\text { palatine } \\
\text { tonsils }\end{array}$ & NA & African/heterosexual & 135/NA & A/alive 1 year later \\
\hline 11 & M & 27 & Palatine tonsils & NA & Caucasian/homosexual & 62/NA & A/alive 1 year later \\
\hline 12 & $\mathrm{~F}$ & 33 & Adenoids & Enlargement & Caucasian/heterosexual & $177 /<4000$ & $\begin{array}{l}\text { B/DOD } 3 \text { years } \\
\text { later }\end{array}$ \\
\hline 13 & M & 28 & Adenoids & $\begin{array}{l}\text { Polypoid mass, } \\
\text { otitis serosa }\end{array}$ & Caucasian/bisexual & $229 / 70000$ & A/alive 1 year later \\
\hline 14 & M & 35 & $\begin{array}{l}\text { Adenoids, } \\
\text { palatine } \\
\text { tonsils }\end{array}$ & $\begin{array}{l}\text { Enlargement, } \\
\text { recurrent } \\
\text { tonsillitis }\end{array}$ & African/heterosexual & $426 / 10670$ & A/alive 1 year later \\
\hline 15 & M & 43 & $\begin{array}{l}\text { Adenoids, } \\
\text { palatine } \\
\text { tonsils }\end{array}$ & Enlargement & African/heterosexual & $17 / 96459$ & C/alive \\
\hline 16 & $\mathrm{~F}$ & 4 & Adenoids & $\begin{array}{l}\text { Enlargement, otitis } \\
\text { serosa }\end{array}$ & African/feto-maternal & $1280 /<400$ & A/alive \\
\hline 17 & $\mathrm{~F}$ & 4 & $\begin{array}{l}\text { Adenoids, } \\
\text { palatine } \\
\text { tonsils }\end{array}$ & $\begin{array}{l}\text { Nasopharyngeal } \\
\text { obstruction }\end{array}$ & African/feto-maternal & $828 / 1298$ & A/B 1 year later \\
\hline 18 & M & 11 & $\begin{array}{l}\text { Adenoids, } \\
\text { palatine } \\
\text { tonsils }\end{array}$ & Enlargement & African/feto-maternal & $343 / 119000$ & A/alive \\
\hline 19 & M & 6 & $\begin{array}{l}\text { Adenoids, } \\
\text { palatine } \\
\text { tonsils }\end{array}$ & Enlargement & African/feto-maternal & $590 / 104000$ & A/alive \\
\hline 20 & $\mathrm{~F}$ & 25 & Adenoids & Slow growing mass & African/heterosexual & $159 / 49500$ & A/alive \\
\hline 21 & $\mathrm{~F}$ & 30 & Adenoids & Enlargement & African/heterosexual & 194/NA & A/alive \\
\hline
\end{tabular}

NA, not available; DOD, dead of disease.

* The viral load was determined by nucleic acid sequence based analysis (NASBA).

** The HIV status at time of biopsy was defined according to the 1993 revised classification system for HIV infection and expanded surveillance case definition for AIDS among adolescents and adults (Centers for Disease Control and Prevention (CDC), MMWR 1992; 41(No. RR-17).

3'. The PCR mixture contained $10 \mathrm{~mm}$ Tris- $\mathrm{HCl}(\mathrm{pH}$ 9), $50 \mathrm{~mm} \mathrm{KCl}, 0.1 \%$ Triton X-100, $200 \mu \mathrm{M}$ dNTP, 12.5 picamoles of each primer, and 1 Taq Bead Hot Start polymerase wax bead containing 1.25 U Taq polymerase (Promega) in a final volume of $25 \mu \mathrm{L}$. PCR conditions were as follows: 5 minutes at $94^{\circ} \mathrm{C}$; 40 cycles of 1 minute at $94^{\circ} \mathrm{C}, 1$ minute at $55^{\circ} \mathrm{C}$, and 1 minute at $72^{\circ} \mathrm{C}$; a final elongation of 7 minutes followed at $72^{\circ}$ C. After amplification, $18 \mu \mathrm{L}$ of PCR product was run on a $2 \%$ agarose gel stained with ethidium bromide.

Positive control for HHV-8 presence consisted of paraffin-embedded tissue sections that originated from an HIV-seropositive patient with a known HHV-8-positive Kaposi's sarcoma and that was processed similarly to the tonsil samples.

\section{RESULTS}

In most cases, the biopsy or the surgical resection was performed because of a clinically unexplained enlargement of the adenoids and/or tonsils (Table $1)$.

MGCs were found in 14 patients $(66.7 \%)$, seven men and seven women. The age of these patients ranged from 4 to 43 years (mean age, 27.6 y; median age, $30 \mathrm{y}$ ). In each case, the number of MGCs varied from 1 to more than 10 per slide. In all of these cases, the histological appearance of the adenoid/ tonsillar lymphoid tissue was that of a follicular hyperplasia with prominent germinal centers, occasional irregular outlines, and/or folliculolysis. 


\begin{tabular}{|c|c|c|c|c|c|c|c|c|c|c|c|c|}
\hline $\begin{array}{c}\text { Case } \\
\text { Number }\end{array}$ & $\begin{array}{c}\text { Histological } \\
\text { Features }\end{array}$ & 3A5 & HLA-DR & $\begin{array}{l}\text { S-100 } \\
\text { Protein }\end{array}$ & CD68 & CDla & CD21 & CD35 & CD83 & $\mathrm{p} 24$ & EBV & HHV8 \\
\hline 1 & Atrophy & & & & & & & & & & & \\
\hline 2 & FH, MGC & + & + & + & + & - & - & - & - & + & - & NA \\
\hline 3 & FH & & & & & & & & & & & \\
\hline 4 & FH, MGC & + & + & - & + & - & NA & NA & - & NA & NA & NA \\
\hline 5 & $\mathrm{FH}$ & & & & & & & & & & & \\
\hline 6 & $\mathrm{FH}$ & & & & & & & & & & & \\
\hline 7 & FH, MGC & + & + & - & + & - & - & - & - & + & - & - \\
\hline 8 & FH, MGC & + & NA & + & + & - & - & - & - & + & - & NA \\
\hline 9 & FH, MGC & + & - & - & + & - & NA & NA & NA & NA & NA & - \\
\hline 10 & FH, MGC & + & + & + & + & - & - & - & - & + & - & - \\
\hline 11 & FH & & & & & & & & & & & \\
\hline 12 & FH, MGC & + & + & - & + & NA & - & - & - & + & - & NA \\
\hline 13 & FH, MGC & + & + & - & + & - & - & - & - & + & NA & - \\
\hline 14 & FH, MGC & + & NA & NA & + & - & NA & NA & NA & NA & NA & NA \\
\hline 15 & $\begin{array}{l}\text { FH, MGC, } \\
\text { DLBCL }\end{array}$ & + & + & + & + & - & - & NA & - & NA & NA & - \\
\hline 16 & FH & & & & & & & & & & & \\
\hline 17 & FH, MGC & + & + & - & + & - & - & - & - & - & - & NA \\
\hline 18 & FH, MGC & + & + & + & + & - & - & NA & - & + & NA & NA \\
\hline 19 & FH & & & & & & & & & & & \\
\hline 20 & FH, MGC & NA & NA & NA & NA & NA & NA & NA & NA & NA & NA & NA \\
\hline 21 & FH, MGC & + & + & NA & + & NA & - & - & - & - & - & NA \\
\hline
\end{tabular}

FH, follicular hyperplasia; MGC, presence of multinucleated giant cells; DLBCL, diffuse large B-cell lymphoma; NA, not available.

MGCs were mostly localized in or just beneath the lymphoepithelium (Fig. 1, A-B). In rare instances, they were also encountered in the interfollicular areas or in close contact with the mantle zone of the follicles. Simultaneous involvement of both adenoids and/or tonsils by MGCs was seen in three patients, whereas in three patients, MGCs were found in successive samples in a few months' interval. In one case, these cells were observed in the residual and hyperplastic tonsillar tissue surrounding a diffuse large B-cell lymphoma.

Immunohistochemical analysis of the MGCs showed constant expression of CD68 (13/13), 3A5 (13/13; Fig. 2), and MHC Class II antigens (10/11). S-100 protein expression was seen in $5 / 11$ cases (45\%; Fig. 3). In these cases, the intensity of the immunostaining was occasionally weaker than that of DCs found in both lymphoepithelium and interfollicular areas. No CD1a, CD21, CD35, or CD83 immunoreactivity could be demonstrated (respectively, $0 / 11,0 / 10,0 / 8$, and $0 / 10$ analyzable cases; Fig. 4). In all the cases tested, the staining with monoclonal antibody directed against the HIV p24 protein characteristically outlined the FDC network in the germinal centers as well as some lymphoid cells in the interfollicular areas. Its immunoexpression by MGCs was recorded in $7 / 9$ cases $(77 \%)$. No EBV-encoded RNA transcript could be demonstrated in the MGCs (0/7), whereas scattered EBVencoded RNA positive lymphocytes were frequently found in the surrounding lymphoid tissue. No HHV-8 DNA could be demonstrated by PCR analysis in the five cases suitable for such investigation.

\section{DISCUSSION}

This work further defines the nature of MGCs that are found in hyperplastic lymphatic tissue of the WR in HIV-seropositive patients. These particular cells have been studied only recently, and studies dealing with that matter are scarce $(3-6,8-10)$ and often originate from the same investigation group (4-6). Because of their S-100 protein and fascin expression on one hand and their striking resemblance to HIV-producing DC-T cell syncytia that are observed in in vitro studies on the other hand, some authors have suggested that MGCs originated from DCs $(4-7,14,15)$. The large number of cases collected in our study, together with the use of a broad panel of antibodies that specifically recognize distinct markers of DCs, FDCs, and macrophages, allow additional comments to be made.

MGCs were found in $66.7 \%$ of our patients, irrespective of gender, age, method of viral transmission, CD4 cell count, viral load, or ethnic group. This percentage, which is in agreement with those of published series, can give a reasonable idea of the overall incidence of this feature in HIVassociated lymphatic hyperplasia of the WR. In this respect, it is worth noting that most of our negative cases were, in fact, small biopsies with relatively small amounts of analyzable tissue.

In our hands, MGCs were found to be $\mathrm{CD}^{+} 8^{+}$, $35^{+}$, MHC Class $\mathrm{II}^{+}, \mathrm{S}-100$ protein $^{+/-}, \mathrm{CDla}^{-}$, $\mathrm{CD} 21^{-}, \mathrm{CD}^{-} 5^{-}$, and $\mathrm{CD} 83^{-}$. With regard to the specificity of these various markers, both PG-M1 and 3A5 antibodies recognize fixative-resistant epitopes that are normally expressed by macrophages $(16,17)$. These monoclonal antibodies do 


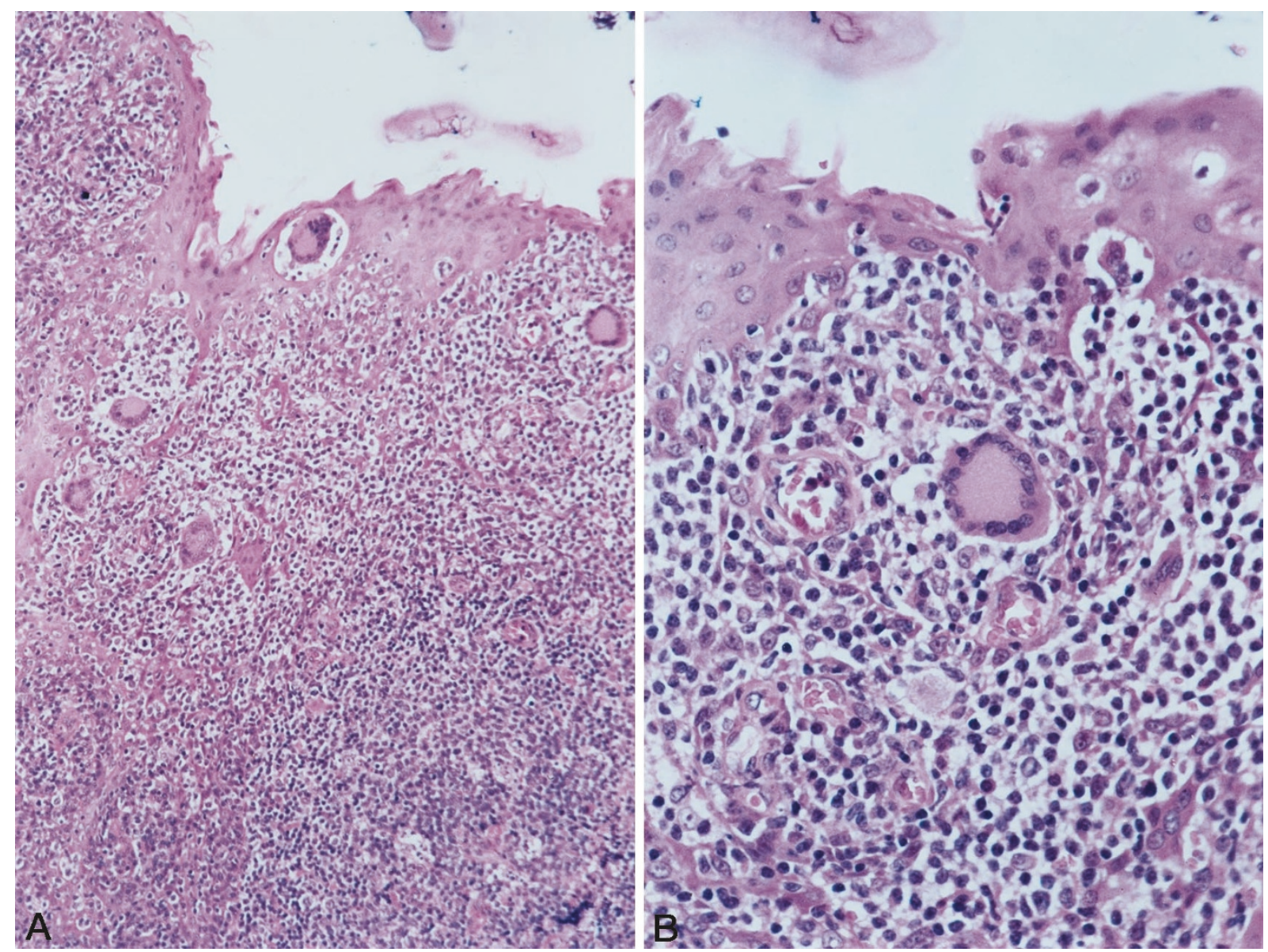

FIGURE 1. Hematoxylin- and eosin-stained sections (A, B) of a tonsillectomy specimen featuring numerous multinucleated giant cells. These characteristic cells are localized in proximity to the lymphoepithelium area.

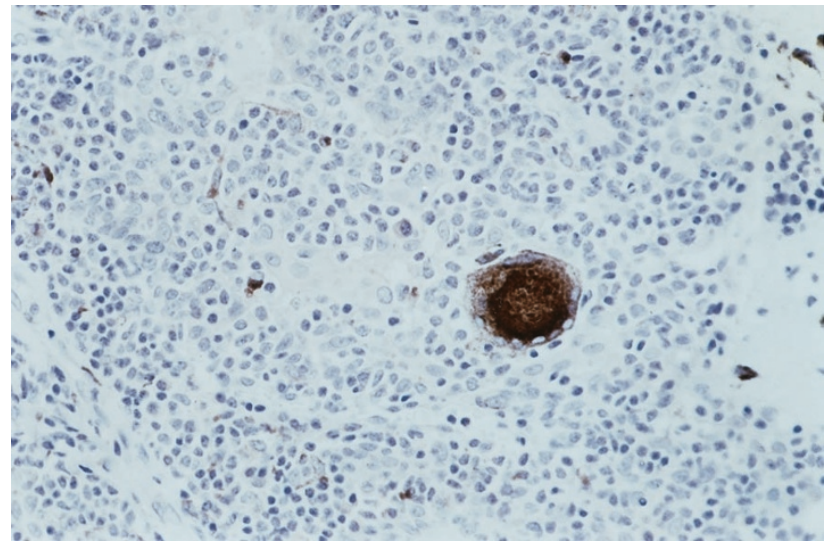

FIGURE 2. Immunostaining with $3 A 5$ antibody. This multinucleated giant cell shows a strong immunoreactivity.

not react with antigen-presenting cells such as interdigitating reticulum cells, Langerhans cells (LCs), or FDCs $(16,17)$. In contrast, CD83 is a DC lineage antigen (19-21). It belongs to the immunoglobulin superfamily, and its expression on DCs is upregulated after activation $(19,20)$. This molecule is also expressed on other cell types such as LCs, FDCs, germinal centers, and activated blood lym-

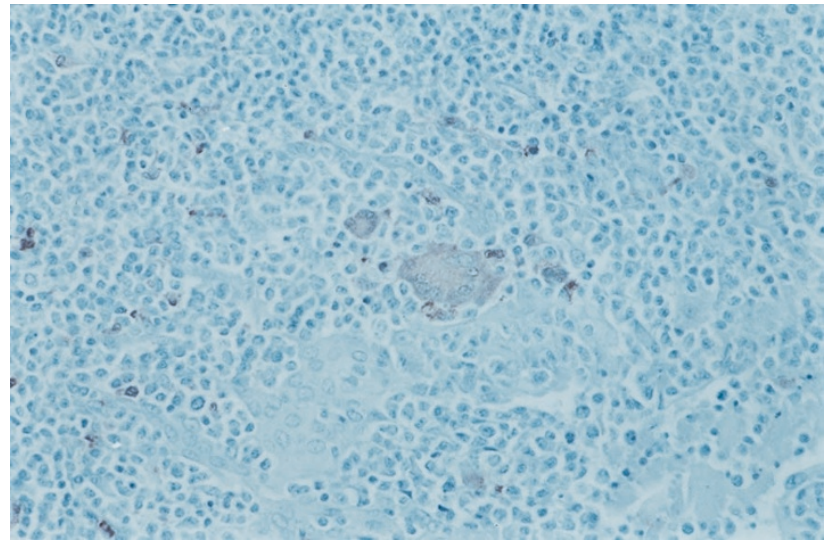

FIGURE 3. Immunostaining with antibody directed against S-100 protein. In this case, multinucleated giant cells were found to be weakly immunoreactive. Note that surrounding dendritic cells also yield staining.

phocytes (19). CDla is a useful marker of DCs that belong to the LC family $(21,22)$, whereas CD21 and CD35 preferentially stain FDCs (22). MHC Class II antigens are expressed on all $\mathrm{B}$ cells, activated $\mathrm{T}$ lymphocytes, monocytes, and macrophages and on all DC populations, including interdigitating reticulum cells, LCs, and FDCs $(20,21)$. As a result, we 


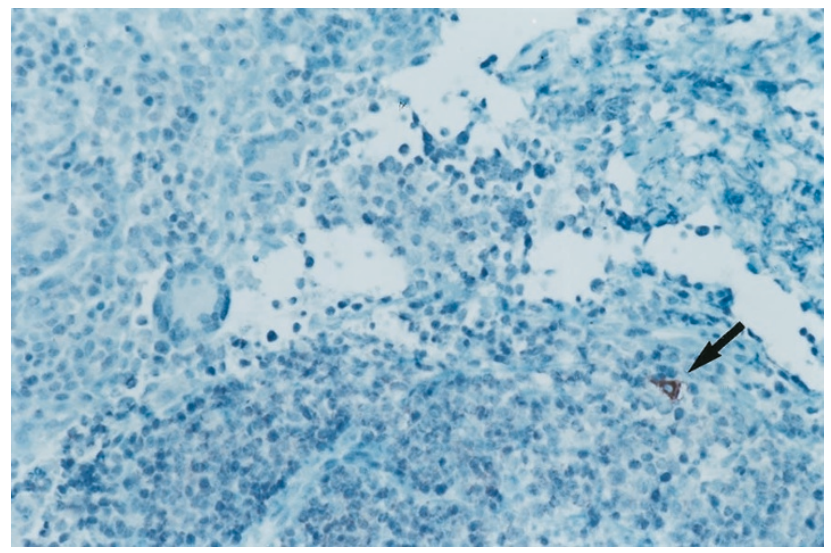

FIGURE 4. Immunostaining with antibody directed against CD83. This multinucleated giant cell is characteristically negative. Note a strongly stained dendritic cell (arrow).

think that the inconstant or weak S-100 protein immunoreactivity that characterizes MGCs and their lack of CD83 expression, together with their PG-M1 and 3A5 reactivity, are in favor of a macrophage phenotype.

Notwithstanding that $\mathrm{S}-100$ protein expression is usually considered a consistent feature of DCs (46), this marker lacks specificity because it can also be expressed by various histiocyte subsets $(23,24)$. Furthermore, its expression by macrophages has been documented in various diseases such as Rosai-Dorfman disease (25), multibacillary leprosy (26), and HIV infection $(27,28)$. In all of these conditions, this apparently aberrant expression was demonstrated to be associated with down- or upregulation of other markers, thereby suggesting functional alterations that are probably related to the underlying immune or infectious disorder (25-28).

Because of the consistent presence of HIV in MGCs in our study as well as in those of others (3-6, 8-13) and because no EBV or HHV-8 could be demonstrated in these cells, we think that the morphology as well as the phenotype of MGCs may be a direct consequence of their infection by this retrovirus. In this respect, the presence in our study of MGCs that are simultaneously p24 negative or weakly positive and S-100 protein negative (Cases 7, 12 , and 17) is interesting. This observation, which suggests that a significant viral load in the macrophage is necessary to induce phenotypic changes such as S-100 protein expression, is in keeping with the knowledge that HIV-infected macrophages display significant alterations of their immune functions, despite their relative resistance to the virus cytopathic effects $(29,30)$. Moreover, HIV-1 infection of primary monocytes but not of monocytederived macrophages has been demonstrated to induce cellular alterations as well as generation of MGCs in in vitro studies (31).
The preferential localization of MGCs in the lymphoepithelium and, to a lesser extent, in the interfollicular zones, in conjunction with a follicular hyperplasia suggests a specific role for these cells in the tonsillar HIV-associated immune response. Both lymphoepithelium and interfollicular areas are indeed specialized trafficking sites at which antigens can be processed and/or presented by antigen-presenting cells to other immune effector cells to initiate a specific response $(14,32)$. In this regard, it is worth noting that macrophages are normally present in the lymphoepithelium area, where they maintain close relationships with $\mathrm{M}$ cells (33). The latter are a highly specialized cellular component of the mucosa-associated lymphoid tissue that acts as a gateway for various antigens that are present in the body cavities, like the nasopharynx (33). Such antigens are processed and/or forwarded through the cytoplasmic invaginations of M-cells, which subsequently present them to the various immune effector cells circulating in the lowest part of the lymphoepithelium $(14,32-34)$. In keeping with the findings of Fais et al. (31), we can therefore speculate that MGCs probably result from the transmigration and homotypic fusion of blood monocytes that are infected by HIV present in the nasopharyngeal secretions during the circulation of these cells in the lymphoepithelium area.

The persistence of MGCs in the same anatomic sites, at several months' interval, also suggests that this phenomenon is chronic. This finding is consistent with the knowledge that macrophages are a long-lived HIV reservoir, thereby providing a continuous source of virus for de novo infection of susceptible target cells that reside and/or circulate in the lymphoid tissue (35-37).

Although the DC origin of MGCs is an attractive supposition, given the lack of specificity of both S-100 protein and fascin, because they are also expressed by macrophages or other cell types (23$28,38)$, we think that assessing the DC lineage by merely studying these markers is insufficient to validate such a hypothesis. Whatever their precise ontogeny, the detection of these very characteristic cells in hyperplastic lymphatic tissues of the WR at least has the merit of alerting the pathologist to the possibility of an underlying HIV infection.

Acknowledgments: This study was supported by the Vesalius Foundation, CHU Saint-Pierre, thanks to a grant from La Loterie Nationale.

\section{REFERENCES}

1. Marcusen DC, Sooy CD. Otolaryngologic and head and neck manifestations of acquired immunodeficiency syndrome (AIDS). Laryngoscope 1985;95:401-5. 
2. Stern JC, Lin PT, Lucente FE. Benign nasopharyngeal masses and human immunodeficiency virus infection. Arch Otolaryngol Head Neck Surg 1990;116:206-8.

3. Rinfret A, Latendresse H, Lefebvre R, St-Louis G, Jolicoeur P, Lamarre L. Human immunodeficiency virus-infected multinucleated histiocytes in oropharyngeal lymphoid tissues from two asymptomatic patients. Am J Pathol 1991;138: 421-6.

4. Frankel SS, Wenig BM, Burke AP, Mannan P, Thompson LDR, Abbondanzo S, et al. Replication of HIV-1 in dendritic cell-derived syncytia at the mucosal surface of the adenoid. Science 1996;272:115-7.

5. Wenig BM, Thompson LD, Frankel SS, Burke AP, Abbondanzo SL, Sesterhenn I, et al. Lymphoid changes of the nasopharyngeal and palatine tonsils that are indicative of human immunodeficiency virus infection. Am J Surg Pathol 1996;20:572-87.

6. Frankel SS, Tenner-Racz K, Racz P, Wenig BM, Hansen CH, Heffner D, et al. Active replication of HIV-1 at the lymphoepithelial surface of the tonsil. Am J Pathol 1997;151:89-96.

7. Frankel SS, Wenig BM, Ferlito A. Human immunodeficiency virus-1 infection of the lymphoid tissues of Waldeyer's ring. Ann Otol Rhinol Laryngol 1997;106:611-8.

8. Soontornniyomkij V, Wang G, Kapadia SB, Achim CL, Wiley CA. Confocal microscopy assessment of lymphoid tissues with follicular hyperplasia from patients infected with human immunodeficiency virus type 1. Arch Pathol Lab Med 1998;122:534-8.

9. Orenstein JM, Wahl SM. The macrophage origin of the HIVexpressing multinucleated giant cells in hyperplastic tonsils and adenoids. Ultrastruct Pathol 1999;23:79-91.

10. Kapadia SB, Wiley CA, Soontornniyomkij V, Wang G, Swerdlow SH. HIV-associated Waldeyer's ring lymphoid hyperplasias: characterization of multinucleated giant cells and the role of Epstein-Barr virus. Hum Pathol 1999;30:1383-8.

11. Gray F, Gaulard P, Le Bezu M, Sinclair E, Gherardi R, Scaravilli $\mathrm{F}$, et al. HIV encephalitis-like multinucleated giant cells in a nodal lymphoma in AIDS. Histopathology 1990;16:402-5.

12. Vicandi B, Jiménez-Heffernan JA, López-Ferrer P, Patrón M, Gamallo C, Colmenero C, et al. HIV-1 (p24)-positive multinucleated giant cells in HIV-associated lymphoepithelial lesion of the parotid gland. Acta Cytol 1999;43:247-51.

13. Lewin-Smith M, Wahl SM, Orenstein JM. Human immunodeficiency virus-rich multinucleated giant cells in the colon: a case report with transmission electron microscopy, immunohistochemistry, and in situ hybridization. Mod Pathol 1999;12:75-81.

14. Pope M. Mucosal dendritic cells and immunodeficiency viruses. J Infect Dis 1999;179(3 Suppl):S427-30.

15. Steinman RM, Granelli-Piperno A, Tenner-Racz K, Racz P, Frankel S, Delgado E, et al. Dendritic cells during infection with HIV-1 and SIV. In: Lotze MT, Thomson AW, editors. Dendritic cells. Biology and clinical applications. 1st ed. San Diego, CA: Academic Press, 1999. p. 421-34.

16. Falini B, Flenghi L, Pileri S, Gambacorta M, Bigerna B, Durkop H, et al. PG-M1: a new monoclonal antibody directed against a fixative-resistant epitope on the macrophage-restricted form of the CD68 molecule. Am J Pathol 1993;142:1359-72.

17. Jaspars EH, Bloemena E, Bonnet P, Scheper RJ, Kaiserling E, Meijer CJLM. A new monoclonal antibody (3A5) that recognises a fixative resistant epitope on tissue macrophages and monocytes. J Clin Pathol 1994;47:248-52.

18. Chang Y, Cesarman E, Pessin MS, Lee F, Culpepper J, Knowles DM, et al. Identification of herpesvirus-like DNA sequences in AIDS-associated Kaposi's sarcoma. Science 1994;266:1865-9.
19. Zhou L, Tedder TF. Human blood dendritic cells selectively express CD83, a member of the immunoglobulin superfamily. J Immunol 1995;154:3821-35.

20. Banchereau J, Steinman RM. Dendritic cells and the control of immunity. Nature 1998;392:245-52.

21. Wright-Browne V, McClain KL, Talpaz M, Ordonez N, Estrov Z. Physiology and pathophysiology of dendritic cells. Hum Pathol 1997;28:563-79.

22. Frizzera G, Wu CD, Inghirami G. The usefulness of immunophenotypic and genotypic studies in the diagnosis and classification of hematopoietic and lymphoid neoplasms. An update. Am J Clin Pathol 1999;111:S13-S39.

23. Takahashi K, Isobe T, Ohtsuki Y, Sonobe H, Takeda I, Akagi T. Immunohistochemical localization and distribution of S-100 proteins in the human lymphoreticular system. Am J Pathol 1984;116:497-503.

24. Vanstapel MJ, Gatter KC, De Wolf-Peeters C, Mason DY, Desmet VD. New sites of human S-100 immunoreactivity detected with monoclonal antibodies. Am J Clin Pathol 1986; 85:160-8.

25. Middel P, Hemmerlein B, Fayyazi A, Kaboth U, Radzun HJ. Sinus histiocytosis with massive lymphadenopathy: evidence for its relationship to macrophages and for a cytokinerelated disorder. Histopathology 1999;35:525-33.

26. Cuevas-Santos J, Contreras F, Scott McNutt N. Multibacillary leprosy: lesions with macrophages positive for S100 protein and dendritic cells positive for Factor 13a. J Cutan Pathol 1998;25:530-7.

27. Falk S, Stutte HJ. The spleen in HIV infection-morphological evidence of HIV-associated macrophage dysfunction. Res Virol 1990;141:161-9.

28. Müller H, Takeshita M. In situ immunophenotype of macrophages and lymphocytes in granuloma formation of tuberculous lymphadenitis in HIV-infected and immunocompetent patients. Res Virol 1991;142:159-72.

29. Mosier D, Sieburg H. Macrophage-tropic HIV. critical for AIDS pathogenesis? Immunol Today 1994;15:332-9.

30. Crowe SM. Role of macrophages in the pathogenesis of human immunodeficiency virus (HIV) infection. Aust N Z J Med 1995;25:777-83.

31. Fais S, Borghi P, Gherardi G, Logozzi M, Belardelli F, Gessani S. Human immunodeficiency virus type 1 induces cellular polarization, intercellular adhesion molecule-1 redistribution, and multinucleated giant cell generation in human primary monocytes but not in monocyte-derived macrophages. Lab Invest 1996;75:783-90.

32. Perry M, Whyte A. Immunology of the tonsils. Immunol Today 1998;19:414-21.

33. Neutra MR, Frey A, Kraehenbuhl JP. Epithelial M cells. Gateways for mucosal infection and immunization. Cell 1996;86: 345-8.

34. Stahl-Hennig C, Steinman RM, Tenner-Racz K, Pope M, Stolte N, Mätz-Rensing K, et al. Rapid infection of oral mucosal-associated lymphoid tissue with simian immunodeficiency virus. Science 1999;285:1261-5.

35. Gartner S, Markovits P, Markovitz DM, Kaplan MH, Gallo RC, Popovic M. The role of mononuclear phagocytes in HTLV-III/LAV infection. Science 1986;233:215-9.

36. Orenstein JM, Fox C, Wahl S. Macrophages as a source of HIV during opportunistic infections. Science 1997;276:185761.

37. Schrager LK, D'Souza MP. Cellular and anatomical reservoirs of HIV-1 in patients receiving potent antiretroviral combination therapy. JAMA 1998;280:67-71.

38. Said JW, Pinkus JL, Yamashita J, Mishalani S, Matsumura F, Yamashiro S, et al. The role of follicular and interdigitating dendritic cells in HIV-related lymphoid hyperplasia: localization of fascin. Mod Pathol 1997;10:421-7. 